\title{
Development and characterization of tubular composite ceramic membranes using natural alumino-silicates for microfiltration applications
}

\author{
Boudjemaa Ghouil $^{\text {b }}$, Abdelhamid Harabi ${ }^{\text {a,* }}$, Ferhat Bouzerara ${ }^{\text {a,b }}$, Boukhemis Boudaira ${ }^{\text {a }}$, Abdelkrim Guechi ${ }^{\text {, }}$ \\ Mustafa M. Demir ${ }^{c}$, Alberto Figoli ${ }^{\mathrm{d}}$
}

a Faculty of Exact Science, Physics Department, Ceramics Lab., Constantine Mentouri University, Constantine 25000, Algeria

${ }^{\mathrm{b}}$ Faculty of Exact Science, Physics Department, Laboratory of Condensed Matter Physics and Nanomaterials, Jijel University 18000, Algeria

c Izmir Institute of Technology, Department of Chemistry, 35430 Gülbahçe, Urla, Izmir, Turkey

d Institute on Membrane Technology, ITM-CNR, via P. Bucci, cubo 17/C, 87030 Rende, CS, Italy

\section{A R T I C L E I N F O}

\section{Article history:}

Received 22 January 2015

Received in revised form 10 March 2015

Accepted 11 March 2015

Available online 13 March 2015

\section{Keywords:}

Ceramic tubular membrane

Porous membrane

Clays

Membrane preparation

Water permeability

Porous materials

\begin{abstract}
A B S T R A C T
The preparation and characterization of porous tubular ceramic composite microfiltration membranes, using kaolins and calcium carbonates, were reported. The porous gehlenite $\left(2 \mathrm{CaO} \cdot \mathrm{Al}_{2} \mathrm{O}_{3} \cdot \mathrm{SiO}_{2}\right)$ and anorthite $\left(\mathrm{CaO} \cdot \mathrm{Al}_{2} \mathrm{O}_{3} \cdot 2 \mathrm{SiO}_{2}\right)$ based ceramics were obtained by a solid state reaction. A ceramic support, sintered at $1250{ }^{\circ} \mathrm{C}$, within an average pore size of about $8 \mu \mathrm{m}$, a porosity of about $47 \%$ and a compression strength around $40 \mathrm{MPa}$, was prepared. The microfiltration active top layer was added on the support by a slip casting from clay powder suspensions. The novel microfiltration membrane layer has a thickness of $40 \mu \mathrm{m}$ and an APS value of about $0.2 \mu \mathrm{m}$. This average pore size value was improved and considerably lower than those reported in the literature $(0.5 \mu \mathrm{m})$. The performance of the novel microfiltration ceramic membrane was determined for evaluating both the water permeability and rejection. This proved the potentiality of the membrane produced in the microfiltration field. Moreover, the good adhesion, between the support and the active microfiltration layer membranes, was also proved. A correlation between microstructures of used powders and physicochemical properties was discussed. Finally, the origin of the unique two powder order membrane depositions was also proposed.
\end{abstract}

(c) 2015 Elsevier Inc. All rights reserved.

\section{Introduction}

The use of traditional ceramics, using raw materials instead of industrial chemicals is becoming of more and more interest mainly due to the lower price of the raw material available. Algeria is one of the countries in the world that have abundantly available raw materials, such as calcium carbonates $\left(\mathrm{CaCO}_{3}\right)(\mathrm{CC})$, dolomite $\left(\mathrm{CaCO}_{3} \cdot \mathrm{MgCO}_{3}\right)$, bones (natural derived hydroxyapatite (HA): $\mathrm{Ca}_{10}\left(\mathrm{PO}_{4}\right)_{6}(\mathrm{OH})_{2}$ ), kaolin, feldspar and quartz. Many works have already been published for valorizing these native raw materials, for the production of advanced ceramics [1-7], ceramic membranes [8-19] and bioceramics [20-27]. In particular, in the membrane field the possibility of replacing the more expensive starting materials by cheaper raw materials to be used as a support (which constitutes about $99 \%$ of the filter mass) is significantly important from economic and energetic points of view. In fact, the price of alumina, usually employed as support, is at least 100 times greater than that of kaolin. The other important advantage is the possibility of reducing the sintering temperature from about 1600 to about $1250{ }^{\circ} \mathrm{C}$, when alumina supports are replaced by the raw materials. Other

\footnotetext{
* Corresponding author.

E-mail address: harabi52@gmail.com (A. Harabi).
}

advantages are the relatively lower theoretical density of the prepared supports $\left(2.8 \mathrm{~g} / \mathrm{cm}^{3}\right)$ when compared to that of alumina $\left(3.98 \mathrm{~g} / \mathrm{cm}^{3}\right)$ and the mechanical strength comparable to that of alumina [14]. Actually, a flexural strength of $87 \pm 2 \mathrm{MPa}$ was obtained for $100 \mathrm{wt}$.\% $\mathrm{Al}_{2} \mathrm{O}_{3}$ samples sintered at $1620{ }^{\circ} \mathrm{C}$ for $2 \mathrm{~h}$ [28], while nearly the same flexural strength value ( $87 \pm 6 \mathrm{MPa}$ ) was also measured for compacts sintered only at $1250{ }^{\circ} \mathrm{C}$ for $1 \mathrm{~h}$, using the proposed process. In this work, novel microfiltration (MF) ceramic composite membranes, made of thinner active layer supported on a porous support, have been prepared. Inorganic membranes are gaining a lot of interest in the recent years, thanks to the development of new types of inorganic membranes [28-37]. The inorganic membranes have excellent high thermal, chemical stability, mechanical resistance [8,13,38-43], a longer life-time, ease of cleaning, a low thermal conductivity and a low dielectric constant $[43,44]$. Furthermore, these membranes are found to be able to resist corrosive highly acids and alkali media as well as to withstand high pressure applications.

MF is a membrane process for concentration, purification, and fractionation in diverse fields such as food, textile, pharmacy, chemical, paper, and leather industries. MF is often used to remove particles, microorganisms, and colloidal materials from suspensions [45-47]. Consequently, preparing inorganic membranes, especially ceramic 


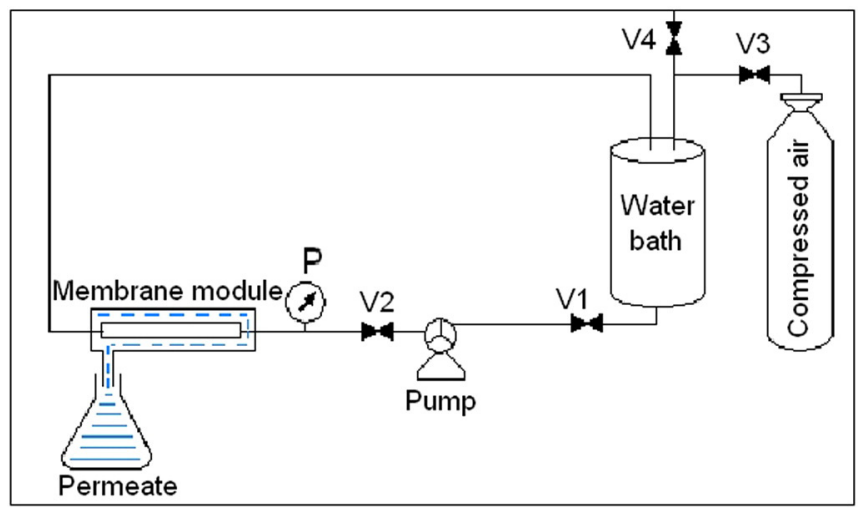

Fig. 1. A schematic process used for the filtration system.

composite membranes [48-56], for these applications are of high interest. Several materials are usually employed for the preparation of ceramics membranes, such as alumina, zirconia and titania. However, natural raw materials, such as kaolin (chemical structure: $\left.\mathrm{Al}_{2} \mathrm{O}_{3} \cdot 2 \mathrm{SiO}_{2} \cdot 2 \mathrm{H}_{2} \mathrm{O}\right)[57,58]$ are more and more used for preparing porous ceramics membranes [9-12,59-68] and it has been used in this work as a starting material.

This membrane is fabricated in different steps. The first step is the preparation of macro porous tubular ceramic support from the Texenna kaolin halloysite type (TKH) and 20 wt.\% CC mixtures, using an extrusion method. The second step is the synthesis of intermediate membrane using a coating method. This layer is necessary to minimize the surface defects and improve the surface roughness of the membrane support for obtaining a small thickness of the top membrane layer. The thin membrane has the double advantage of reducing the cost of material needed and also of increasing the permeate flux. After sintering of the intermediate layer, a top membrane layer is subsequently deposited. The MF composite ceramic membranes were characterized for evaluating their morphology, mechanical and chemical properties. Besides, the water flux and rejection of the membranes were also determined for evaluating their potentiality in the water treatment. A correlation between microstructures of used powders and physicochemical properties was furthermore discussed. Finally, the origin of the unique 2 powder order membrane depositions was also discussed.

\section{Experimental procedures}

\subsection{Raw materials}

A natural Texenna kaolin halloysite type (TKH), a Tamazert kaolin (TK) and CC (99.6\% purity) powder were used as starting materials.
These raw materials were obtained from Jijel and Constantine regions (Algeria), respectively. CC powder was used as a pore former. The particle size distribution of TKH and CC material was determined by the Dynamic Laser Beam Scattering (DLBS) technique. The organic additives, Amijel and methocel (methylcellulose) were used in order to improve the rheological properties of the paste that facilitate the forming of supports.

\subsection{Supports elaboration}

Porous tubular membrane supports were fabricated from clay (TKH) and CC mixtures. The kaolin powder was then ground and sieved through a $150 \mu \mathrm{m}$ sieve. The average particle size of CC was around $5 \mu \mathrm{m}[9]$.

The selected composition of powders used for the plastic paste preparation was 75 wt.\% Kaolin (TKH), 19 wt.\% CC powder, 3 wt.\% Amijel as a binder and 3 wt.\% Methocel as a plasticizer. The powder mixture was aged with a progressive addition of water to obtain a plastic paste with a good homogeneity and to allow the shaping. Subsequently, the paste was left for $12 \mathrm{~h}$ under a high humidity to improve its rheological property. The initial tubular supports were obtained by the extruding of the paste to form cylindrical tubular supports having the following dimensions: $6 \mathrm{~mm}$ (I.D.) and $10 \mathrm{~mm}$ (O.D.) while the length of the supports was according to our needs (the one which was used was $20 \mathrm{~cm}$ long). The (I.D.) and (O.D.) are the inner and the outer diameters, respectively.

The extruded tubes were placed on rotating rollers to cause the support to rotate so that they dry up and stay straight.

Afterwards, the supports were sintered at different temperatures ranging from 1100 to $1250{ }^{\circ} \mathrm{C}$ for $1 \mathrm{~h}$, with a heating rate of about $4{ }^{\circ} \mathrm{C} / \mathrm{min}$ from $25{ }^{\circ} \mathrm{C}$ to $\mathrm{T}\left({ }^{\circ} \mathrm{C}\right)$. This range of temperatures $\left(1100-1250^{\circ} \mathrm{C}\right)$ was found to be the appropriate one since at lower sintering temperatures we did not obtain the adequate mechanical strength.

\subsection{Membrane preparation}

In this work, multilayer membranes were synthesized. These membrane configurations consist of three layers: a porous support, an interlayer and a top layer. The intermediate layer was prepared from TK [11] and used as a support for the top layer which was made of TKH powders. In fact, due to the particular TKH shape and sizes of particles, coupled with the larger pore diameter of the clay support, it was necessary to coat an intermediate layer with smaller pore sizes compared to the support. The intermediate layer has also the role of preventing the infiltration of suspensions into the support. The procedure for the preparation of the TK intermediate membrane layer was similar to that which was already described in a previous paper. This
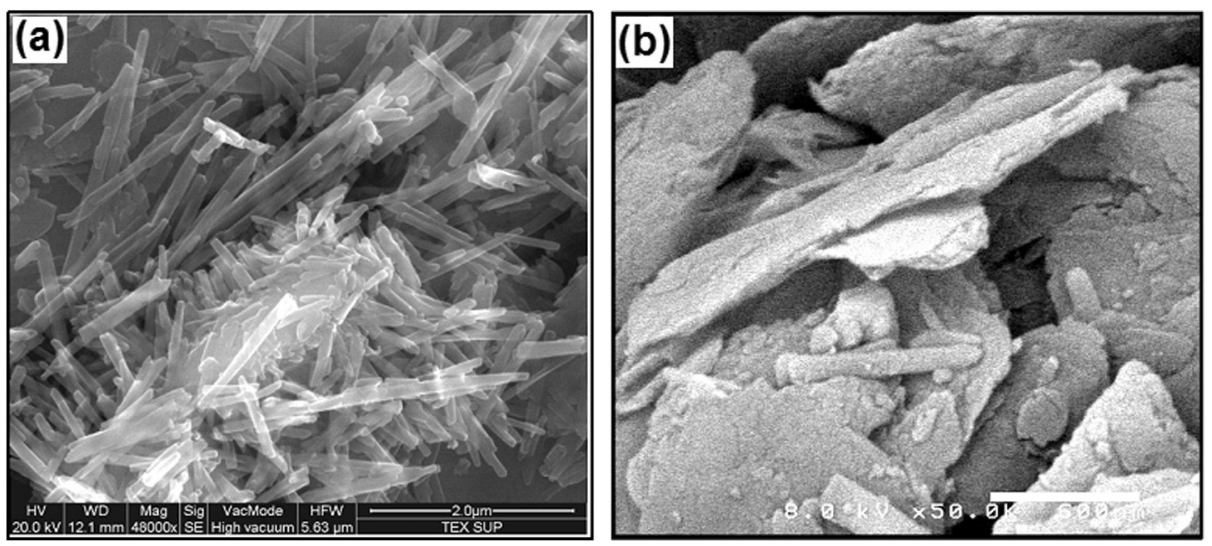

Fig. 2. SEM micrographs of the powders: (a): TKH, (b): TK. 


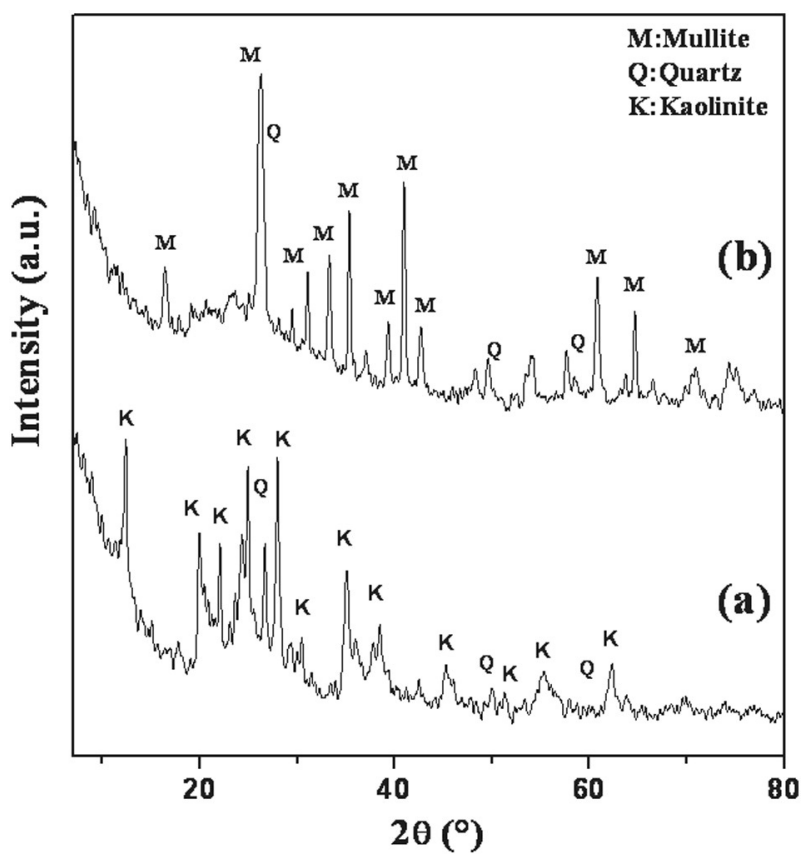

Fig. 3. XRD spectra of the kaolin TKH, a: before and, b: after sintering at $1150{ }^{\circ} \mathrm{C}$ for $1 \mathrm{~h}$.

powder gives an APS of about $0.5 \mu \mathrm{m}$ [11]. Deposition of the intermediate layer was performed with a colloidal process. This involves the preparation of a stable suspension, using $10 \mathrm{wt} . \%$ of TK, $30 \mathrm{wt}$.\% of polyvinyl alcohol (PVA) (12 wt.\% aqueous solution) and water $60 \mathrm{wt} . \%$. The suspension was then deposited on the support using the slip casting method (the deposition time was about $10 \mathrm{~min}$ ). The used support, sintered at $1250{ }^{\circ} \mathrm{C}$, has an APS of $8 \mu \mathrm{m}$ and $47 \%$ porosity. The system was dried vertically for about $12 \mathrm{~h}$ at room temperature and it was subsequently sintered at $1150{ }^{\circ} \mathrm{C}$ for $1 \mathrm{~h}$ with a heating rate of about $4^{\circ} \mathrm{C} / \mathrm{min}$. This temperature was selected because it allows the obtention of the adequate characteristics of the membrane, precisely, the adhesion between support and membrane.

For preparation of TKH MF membranes, the same powder used for support preparation was crushed and calibrated by sieving at $50 \mu \mathrm{m}$. The specific surface area of the TKH powder was about $20 \mathrm{~m}^{2} / \mathrm{g}$.

The membrane solution was prepared by adding TKH powder (15 wt.\%) into distilled water (57 wt.\%) and stirred for $4 \mathrm{~h}$. Then, the PVA 28 wt.\% (12 wt.\% aqueous solution) was added into the TKH solution and stirred again for $24 \mathrm{~h}$ at a room temperature. The deposition

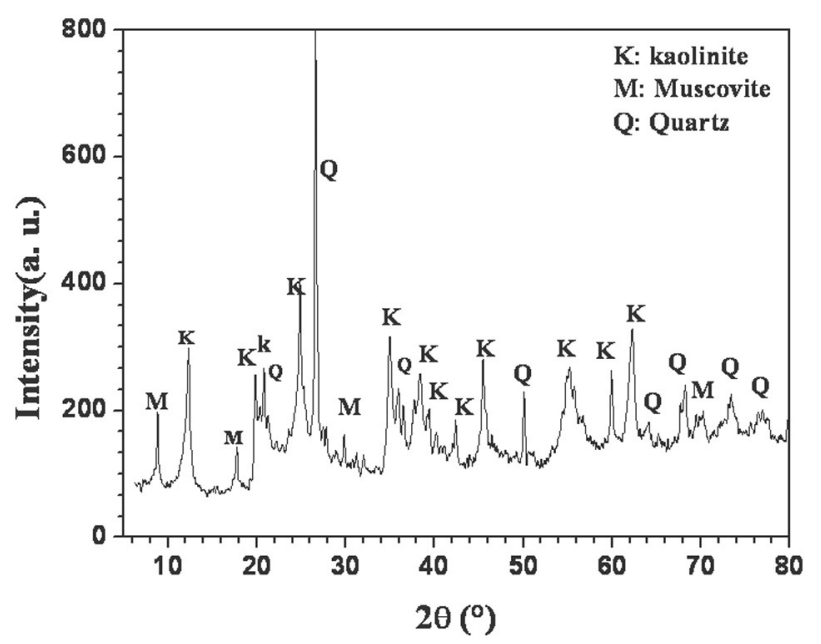

Fig. 4. XRD spectrum of the kaolin TK.
Table 1

Chemical composition of clay using fluorescence XRF analysis.

\begin{tabular}{lllllllllll}
\hline Oxides & $\mathrm{SiO}_{2}$ & $\mathrm{Al}_{2} \mathrm{O}_{3}$ & $\mathrm{~K}_{2} \mathrm{O}$ & $\mathrm{Fe}_{2} \mathrm{O}_{3}$ & $\mathrm{TiO}_{2}$ & $\mathrm{CaO}$ & $\mathrm{MgO}$ & $\mathrm{Na}_{2} \mathrm{O}$ & $\mathrm{MnO}$ & Other \\
\hline wt.\% & 60.28 & 30.38 & 6.02 & 0.70 & 0.25 & 0.22 & 0.17 & 0.11 & 0.06 & 1.81 \\
\hline
\end{tabular}

time was about $5 \mathrm{~min}$. After drying at room temperature for $24 \mathrm{~h}$, the deposited MF layer was sintered at $1050{ }^{\circ} \mathrm{C}$ for $1 \mathrm{~h}$.

\subsection{Characterization techniques}

Different techniques were used to investigate the properties of both kaolin supports and membranes. The structure was determined by $\mathrm{X}$-ray diffraction (XRD) using a Philips X'Pert X-ray diffractometer operating with $\mathrm{Cu} \mathrm{K} \alpha$ radiation $(\lambda=1.54056 \AA$ ). The total porosity, APS or diameter and pore size distribution were determined by a mercury intrusion porosimetry method (Micromeritics, Model Autopore 9220) for samples sintered at different temperatures. The morphology, the surface quality and thickness of intermediate and top-layer membranes were examined with scanning electron microscopy (SEM). The structural properties of the membrane materials were characterized by $\mathrm{X}$-ray diffraction, $\mathrm{N}_{2}$ adsorption, Fourier transform infrared spectroscopy (FTIR - Perkin Elmer Spectrum BX LX 185255), differential thermal analysis (DTA) and thermogravimetric analysis (TGA) using a Perkin Elmer Diomand TG/TDA apparatus. Nitrogen adsorption measurements were performed at $78 \mathrm{~K}$ to determine BET surface area using an ASAP 2020 volumetric adsorption analyzer (from Micromeritcs). Prior to the adsorption measurements, each sample was degassed at $300{ }^{\circ} \mathrm{C}$ for $2 \mathrm{~h}$. The structural evolution of powders was also evaluated by DTA and TGA. These two analyses were carried out under a nitrogen atmosphere, with a heating rate of $10{ }^{\circ} \mathrm{C} / \mathrm{min}$, from $30^{\circ} \mathrm{C}$ to $1000^{\circ} \mathrm{C}$. The mechanical strength of sintered specimens was measured by a compression test with a constant displacement rate of about $0.2 \mathrm{~mm} / \mathrm{min}$, using a universal mechanical testing machine (Zwick 10K) (Germany). The tangential filtration experiments were performed using a home-made laboratory plant at a room temperature and the working pressure was obtained using an air gas source. Fig. 1 shows the schematic of the filtration system.

The permeability characterizes the quantity of water per unit time and area which crosses the membrane at a given pressure. The permeate flux is one of the most important parameters in the evaluation of the performance of a filtration system. The membrane permeation property was characterized by distilled water flux (DWF). The filtration experiments were carried out at a room temperature and DWF was obtained by

$\mathrm{DWF}=\mathrm{Q} /(\mathrm{S} \cdot \mathrm{t} \cdot \mathrm{P})$

where DWF is the permeation flux of membrane for distilled water $\left(1 \cdot h^{-1} \cdot \mathrm{m}^{-2} \cdot \operatorname{bar}^{-1}\right), \mathrm{Q}$ is the volume of the permeated pure water $(\mathrm{l})$, $\mathrm{S}$ is the effective area of the membrane $\left(\mathrm{m}^{2}\right)$, here calculated by the

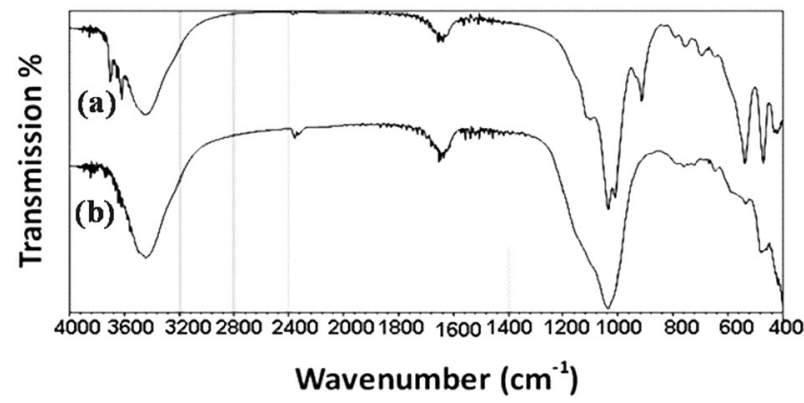

Fig. 5. FTIR spectrum of kaolin, a: before and b: after calcinations at $550{ }^{\circ} \mathrm{C}$ for $1 \mathrm{~h}$. 
Table 2

Attribution band vibrations of the FTIR spectrum of kaolin.

\begin{tabular}{|c|c|c|c|c|c|c|c|c|c|c|c|c|}
\hline $\mathrm{V}\left(\mathrm{cm}^{-1}\right)$ & 415 & 471 & 539 & 694 & 758 & 794 & 914 & 1010 & 1097 & 1640 & 3625 & 3695 \\
\hline Chemical bands & $\mathrm{Si}-\mathrm{O}$ & $\mathrm{Si}-\mathrm{O}$ & $\mathrm{Si}-\mathrm{O}-\mathrm{Al}$ & $\mathrm{Si}-\mathrm{O}$ & $\mathrm{Si}-\mathrm{O}-\mathrm{Al}$ & Si-O-Al & $\mathrm{Al}-\mathrm{OH}$ & $\mathrm{Si}-\mathrm{O}-\mathrm{Si}$ & $\mathrm{Si}-\mathrm{O}$ & $\mathrm{Al}-\mathrm{OH}$ & $\mathrm{OH}$ & $\mathrm{OH}$ \\
\hline References & 57 & 57 & $57-58$ & 57 & 57 & $57-52$ & 57 & $58-52$ & $57-58$ & $58-52$ & $57-52$ & $57-58$ \\
\hline
\end{tabular}

inner diameter of the tubular membrane, $\mathrm{t}$ is the permeation time (h) and $\mathrm{P}$ is the operating pressure (bar).

The retention rate of the membranes was determined by using a solution containing dextran with a molecular weight equal to $40 \mathrm{kDa}$. The concentration of the solution was fixed at $1 \mathrm{~g} / \mathrm{l}$. All the experiments were carried out at a room temperature. Moreover, the retention rates were estimated by the following simple relation:

$\mathrm{R}(\%)=100\left(1-\mathrm{C}_{\mathrm{p}} / \mathrm{C}_{\mathrm{f}}\right)$

where $C_{p}$ and $C_{f}$ are the solute concentration in the permeability and in the feed solution, respectively.

\section{Results and discussion}

\subsection{Analysis of the raw materials}

The SEM pictures of the powders used are shown in Fig. 2. Fig. 2a shows that this TKH crystallizes nicely in the form of naturally hallow nano-rode halloysite crystals. Furthermore, the TKH powder structure is confirmed by XRD spectrum as shown in Fig. 3. Additionally, the TK powder structure is also confirmed by XRD spectrum showed in Fig. 4. Fig. 4 illustrates the XRD pattern of the TK; it confirms that kaolinite $(\mathrm{K})$, quartz $(\mathrm{Q})$ and muscovite $(\mathrm{M})$ are the main crystalline minerals existing in this clay. By contrast, TK has larger particle sizes than TKH and it has lamellar or platelet shaped particles (Fig. 2b). Some particle size proportions of TK were lower than $1 \mu \mathrm{m}$. On the basis of these results, porous TK layer was successfully utilized as intermediate layer in order to prevent the infiltration of the suspensions into the supports. Subsequently, a bi-layered membrane was deposited on anorthite and gehlenite based supports, which were prepared from TKH and CC powders.

The chemical composition of TKH powder, given in weight percentages (wt.\%) of oxides, is illustrated in Table 1. The main elements constituting this kaolin type are $\mathrm{Al}_{2} \mathrm{O}_{3}$ and $\mathrm{SiO}_{2}$ (within 6.02 wt.\% $\mathrm{K}_{2} \mathrm{O}$, 0.70 wt.\% $\mathrm{Fe}_{2} \mathrm{O}_{3}, 0.24$ wt.\% $\mathrm{TiO}_{2}, 0.22$ wt.\% $\mathrm{CaO}, 0.17$ wt.\% $\mathrm{MgO}$ and 0.11 wt.\% $\mathrm{Na}_{2} \mathrm{O}$ as impurities).

The TKH powders were transformed into metakaolin (without the water of hydration) by heat treatment at $550{ }^{\circ} \mathrm{C}$. Then, metakaolin was thermally converted into mullite via high sintering temperature

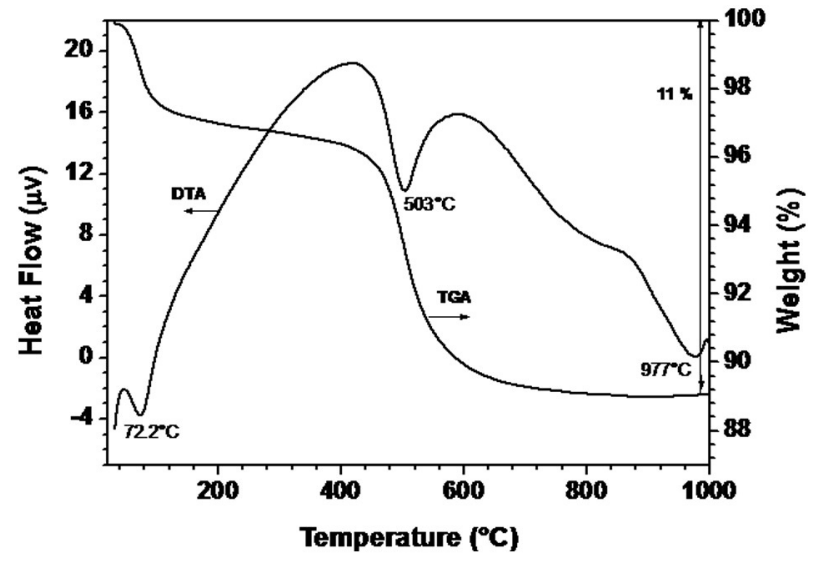

Fig. 6. DSC and TGA curves for kaolin powder. $\left(990{ }^{\circ} \mathrm{C}\right)$. These reactions can be represented by the following equations:

$$
\begin{aligned}
& \left.\mathrm{Si}_{2} \mathrm{O}_{5}(\mathrm{OH})_{4} \mathrm{Al}_{2} \text { (kaolin) } \rightarrow \mathrm{Al}_{2} \mathrm{Si}_{2} \mathrm{O}_{7} \text { (metakaolin }\right)+2 \mathrm{H}_{2} \mathrm{O} \\
& 3\left(\mathrm{Al}_{2} \mathrm{O}_{3} \cdot 2 \mathrm{SiO}_{2}\right) \rightarrow 3 \mathrm{Al}_{2} \mathrm{O}_{3} \cdot 2 \mathrm{SiO}_{2}+4 \mathrm{SiO}_{2} .
\end{aligned}
$$

Fig. 3a shows the phase composition of used kaolin. It can be seen that the main crystallized phase is kaolinite with minor of quartz $\left(\mathrm{SiO}_{2}\right)$. When a sample is sintered at $1150^{\circ} \mathrm{C}$, the reaction between silica and alumina to form mullite phase becomes evident. In fact, the XRD curve (Fig. 3b) shows that the main phases are mullite $\left(3 \mathrm{Al}_{2} \mathrm{O}_{3} \cdot 2 \mathrm{SiO}_{2}\right)$ and quartz $\left(\mathrm{SiO}_{2}\right)$. Besides XRD measurements, FTIR spectroscopy was applied to confirm the kaolinite transformation during its calcination. FTIR spectra obtained for the starting clay and after calcination at $550{ }^{\circ} \mathrm{C}$ for $1 \mathrm{~h}$ are shown in Fig. 5. The results of FTIR spectroscopy of the starting clay (Fig. 5a and Table 2) show the TKH characteristic bands: $\mathrm{Si}-\mathrm{O}$ (at around 426, 466, 696, 1004, and $1110 \mathrm{~cm}^{-1}$ ), Si-O-Al (at around 534, 754, and $786 \mathrm{~cm}^{-1}$ ), Al-OH (at around 910 and $928 \mathrm{~cm}^{-1}$ ) and $\mathrm{OH}$ (at around 3692, 3668, 3650, and $3618 \mathrm{~cm}^{-1}$ ). After calcination at $550^{\circ} \mathrm{C}$ for $1 \mathrm{~h}$ (Fig. $5 \mathrm{~b}$ ), the loss of bands concerning the hydroxide was noticed.

\subsection{Thermal analysis}

The objective of thermal analysis (TGA and DTA) is to identify the structural evolution of the membrane support, where predominant weight losses (and hence transformations) occur in the TKH powder and in the membrane support prepared from TKH $+20 \mathrm{wt} . \%$ CC mixtures (Figs. 6 and 7). The TGA and TDA analyses were carried out under nitrogen atmosphere, from a room temperature to $1000{ }^{\circ} \mathrm{C}$. Fig. 6 shows TGA and DTA measurement results of TKH. Two endothermic and one exothermic peak appear on DTA curve. The thermogravimetric curve shows that the first and second endothermic processes are accompanied by the decrease in the mass sample. The first peak at about $72{ }^{\circ} \mathrm{C}$ may pertain to the evaporation of water adsorbed on the surface. In fact, the sample mass was lowered by about 3\% during this process. However, the endothermic peak corresponding to the hydroxylation of kaolin is located at $503^{\circ} \mathrm{C}$. This sample mass was additionally reduced by about $8 \mathrm{wt} . \%$ during this process.

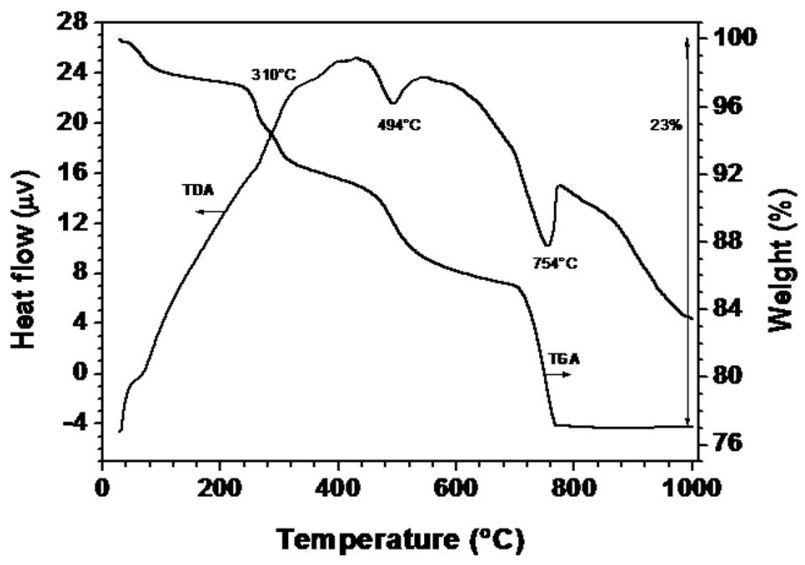

Fig. 7. DSC and TGA for none calcined supports (clay +20 wt.\% CC). 
Table 3

Changes in samples and the phenomena which may probably occur.

\begin{tabular}{|c|c|c|c|c|}
\hline Sample & Range of $\mathrm{T}\left({ }^{\circ} \mathrm{C}\right)$ & TGA & DTA & Phenomena \\
\hline \multirow[t]{3}{*}{ Kaolin } & $25-200$ & Weight loss & Endothermic peak & Evaporation of adhesion water \\
\hline & $450-550$ & Weight loss & Endothermic peak & Dehydration of structured water \\
\hline & $950-1000$ & - & Exothermic peak & Formation of mullite or spinel \\
\hline \multirow[t]{4}{*}{ Kaolin $+\mathrm{CaCO}_{3}+$ amijel + methocel } & $25-250$ & Weight loss & Endothermic peak & Evaporation of adhesion water \\
\hline & $250-350$ & Weight loss & Exothermic peak & Departure of additive organic materials \\
\hline & $450-550$ & Weight loss & Endothermic peak & Dehydration of structured water \\
\hline & $700-800$ & Weight loss & Endothermic peak & Decomposition of $\mathrm{CaCO}_{3}$ to $\mathrm{CaO}$ and $\mathrm{CO}_{2}$ \\
\hline
\end{tabular}

Exothermic peak is located at about $977{ }^{\circ} \mathrm{C}$ whereas TG curve does not show any change. Nevertheless, the origin of this reaction is not completely clear, yet. Some researchers attribute this reaction to spinel formation while others to mullite nucleation [8]. It does not cause weight change as the crystallization. The thermal behavior of the membrane support prepared from TKH +20 wt.\% CC mixtures, in the temperature range from a room temperature to $200{ }^{\circ} \mathrm{C}$, is presented in Fig. 7. The DTA curve shows endothermic peak at $70{ }^{\circ} \mathrm{C}$ while the TGA curve shows a slight decrease in weight ( $3 \mathrm{wt} . \%$ ) until $200^{\circ} \mathrm{C}$. The reason of such decrease is probably due to the water adsorbed in the powder mixture. In the range of 200 to $400{ }^{\circ} \mathrm{C}$, DTA curve shows exothermic peak at $320^{\circ} \mathrm{C}$, whereas TGA curve shows a slight weight decrease (5\%). This decline is probably due to the loss of organic materials, present as additive. In the range of 450 to $550{ }^{\circ} \mathrm{C}$, DTA curve shows a broad endothermic peak at $494{ }^{\circ} \mathrm{C}$. TG curve shows a $7 \%$ weight decrease, which may be due to the dehydration of structured water of kaolin. In the temperature range of 700 to $800{ }^{\circ} \mathrm{C}$, DTA curve shows a sharp endothermic peak at $754{ }^{\circ} \mathrm{C}$ while TG curve shows $7 \%$ weight decrease. The reason of this decrease is related to the decomposition of $\mathrm{CC}$ to $\mathrm{CaO}$ and $\mathrm{CO}_{2}$. Table 3 provides information on the changes in samples, due to decomposition of $\mathrm{CC}$ into $\mathrm{CaO}$ and $\mathrm{CO}_{2}$, which causes the pores' appearance from the particle-particle sintering. The porosity of the membrane supports must depend on the path taken by the $\mathrm{CO}_{2}$ and other volatile materials evolved during sintering.

\subsection{Phase identification}

XRD was used in order to investigate the effect of the calcination temperature on the formed phases. In general, sintering produces a series of reactions or phase transformations that lead to the formation of new phases. In Fig. 8 are depicted typical XRD reflections corresponding to supports sintered at three different temperatures $(1100,1200$ and $1250^{\circ} \mathrm{C}$ ) for $1 \mathrm{~h}$. The main phases identified in the membrane supports are the anorthite $\left(\mathrm{CaO} \cdot \mathrm{Al}_{2} \mathrm{O}_{3} \cdot 2 \mathrm{SiO}_{2}\right)$ which is a predominant phase at $1250{ }^{\circ} \mathrm{C}$ with a minor phase of gehlenite $\left(2 \mathrm{CaO} \cdot \mathrm{Al}_{2} \mathrm{O}_{3} \cdot \mathrm{SiO}_{2}\right)$ where the XRD peak intensities decrease with the increase in sintering temperatures. These identified phases are of great importance because of their promising physical and mechanical properties.

\subsection{Supports morphology}

The SEM images reported in Fig. 9 show the surface and the cross-section of the tubular membrane supports prepared from $\mathrm{TKH}+20 \mathrm{wt} . \% \mathrm{CC}$ sintered at 1200 and $1250{ }^{\circ} \mathrm{C}$ for $1 \mathrm{~h}$, respectively. The two ceramic supports have a very similar surface morphology. This confirms the highly porous structure with a homogeneous pore distribution (even though the presence of large pores is to be noted). The pores are randomly shaped. At the same time, we notice the absence of macro-defects such as cracks. These features are important for the fabrication of good quality supports. The surface quality of the support is important for the good deposition of the membrane. This study confirms that the use of the interlayer membrane is an important parameter for controlling the surface roughness of the ceramic supports.

\subsection{Open porosity and pore size distribution for supports}

Ceramic supports must have a high porosity ratio (percentage of porous volume to total volume), a narrow pore size range, and a higher mechanical strength, as well as a high performance for the chemical nature of the filtered water. The regularity of porous texture in the supports is realized by $\mathrm{CC}$, which would dissociate into $\mathrm{CaO}$ and $\mathrm{CO}_{2}$ gas, under sintering conditions. The path taken by the released $\mathrm{CO}_{2}$ gas creates the porous texture of the ceramic membrane and contributes to the membrane porosity during the sintering process. The open porosity and the APS of the porous membrane supports sintered at different temperatures for $1 \mathrm{~h}$ are illustrated in Fig. 10.

The main remarks that can be drawn from these results is that the increase in the sintering temperature allows to increase the APS and the total porosity of membranes. In particular, the porosity increases slightly while the APS increases sharply from 1150 to $1250{ }^{\circ} \mathrm{C}$. Both the total porosity and the APS of specimens were the lowest at $1100{ }^{\circ} \mathrm{C}$.

As shown in Fig. 10, the porosity remains stable within the sintering temperature change from 1100 to $1150{ }^{\circ} \mathrm{C}$. By contrast, it increases slightly from 41 to $45 \%$ when the sintering temperature is increased from 1150 to $1250{ }^{\circ} \mathrm{C}$, and it goes up to about $47 \%$ with a further increase in the sintering temperature up to $1250{ }^{\circ} \mathrm{C}$.

The APS rises slightly from 1.9 to $2.5 \mu \mathrm{m}$ with the increase in the sintering temperature from 1100 to $1150{ }^{\circ} \mathrm{C}$, and it will go up to $8 \mu \mathrm{m}$ with a further increase in the sintering temperature up to $1250{ }^{\circ} \mathrm{C}$. Therefore, this result at $1250{ }^{\circ} \mathrm{C}(\mathrm{APS} \approx 8 \mu \mathrm{m}$, total porosity $\approx 47 \%$ ) indicates that the porous specimens may be suitable for membrane

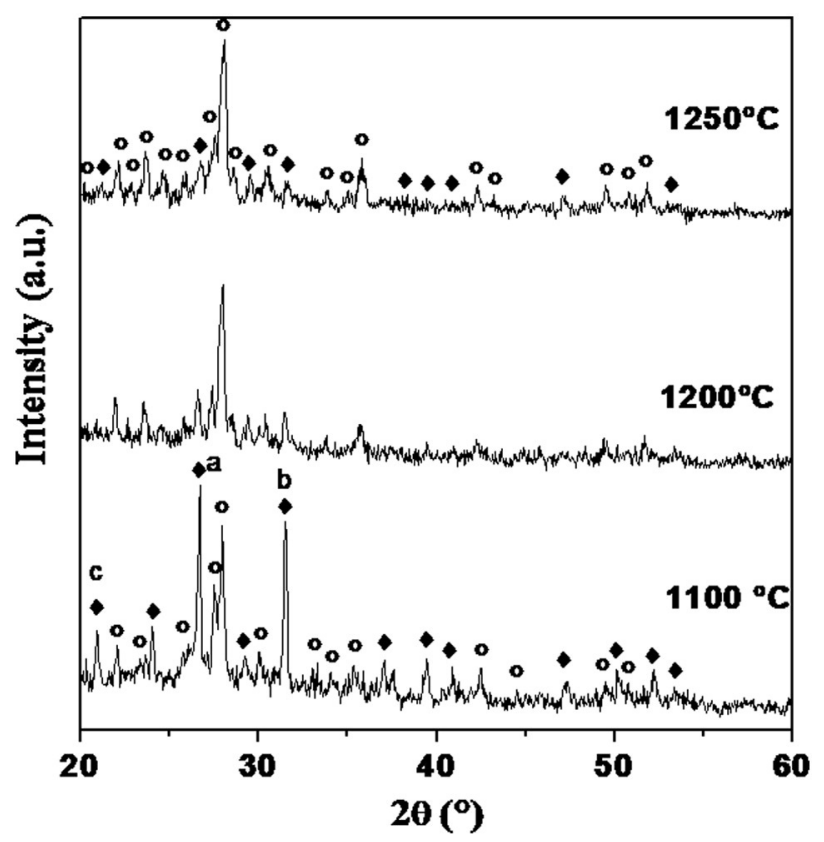

Fig. 8. XRD spectra of support samples sintered at different temperatures for $1 \mathrm{~h}$ : $\bigcirc$ : Anorthite, $\bullet$ : Gehlenite. 

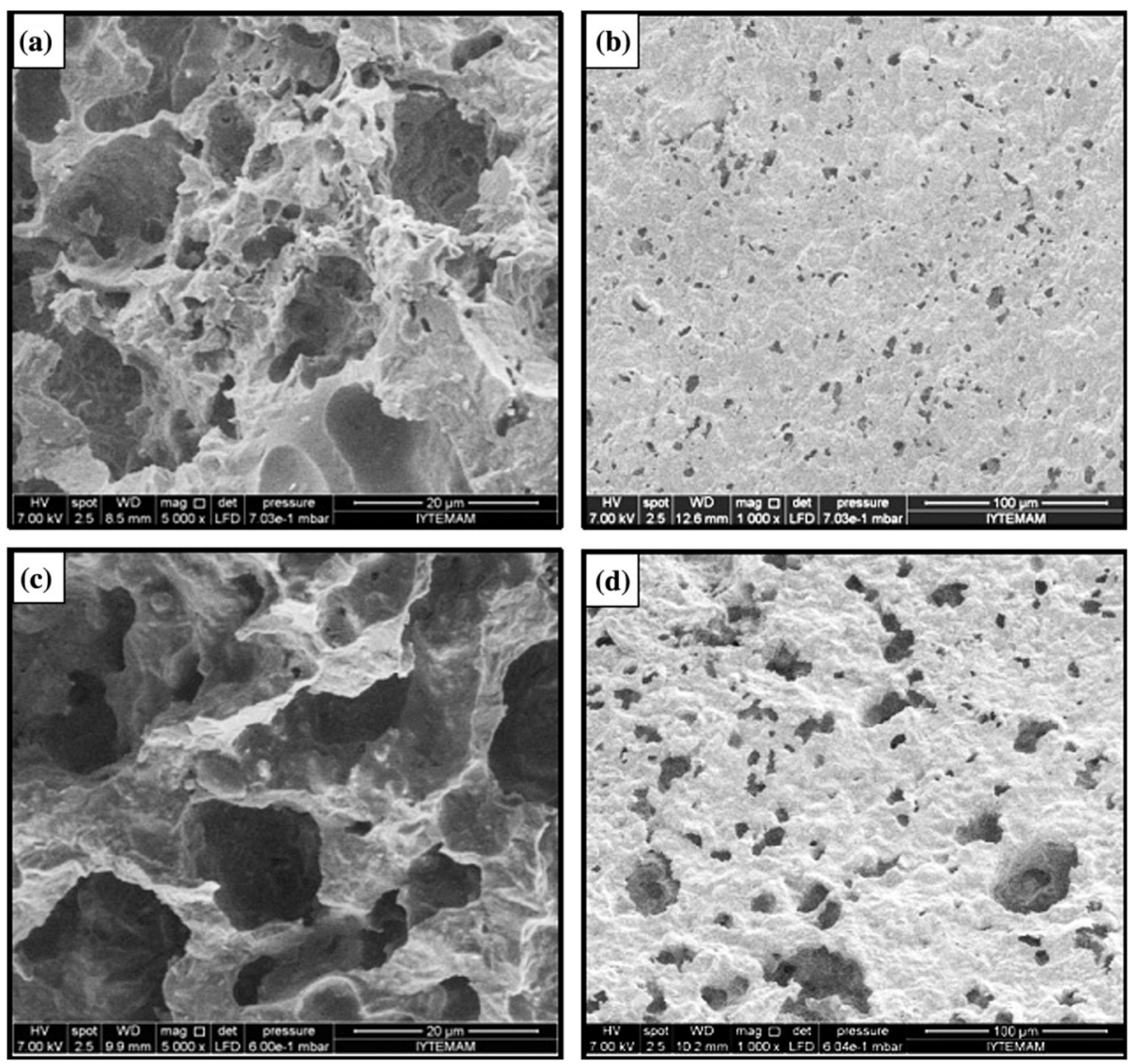

Fig. 9. SEM micrographs of membrane support sintered for $1 \mathrm{~h}$ at 1200 and $1250{ }^{\circ} \mathrm{C}$, respectively: A and C: cross-section, B and D: surface.

support fabrication. The variation of porosity ratio and a high increase in the APS above $1200{ }^{\circ} \mathrm{C}$ are mainly related to the decomposition of gehlenite and the anorthite formation. It can be said that the sintering of the membrane supports at $1250^{\circ} \mathrm{C}$ improves the porosity ratio and the APS. Nevertheless, an increase in these coefficient values may direct to a negative effect on the membrane support properties. This is because the supports having these large pores may encounter difficulties when membrane layers are deposited since powder particles are finer.

The pore size distribution curves of specimens sintered at 1100 , 1150 , and $1250{ }^{\circ} \mathrm{C}$, are illustrated in Fig. 11. As it can be deduced from this figure, the majority of pores had a diameter smaller than $4 \mu \mathrm{m}$, ranging from 0.5 to $4 \mu \mathrm{m}$ for specimens sintered at 1100 and $1150{ }^{\circ} \mathrm{C}$.

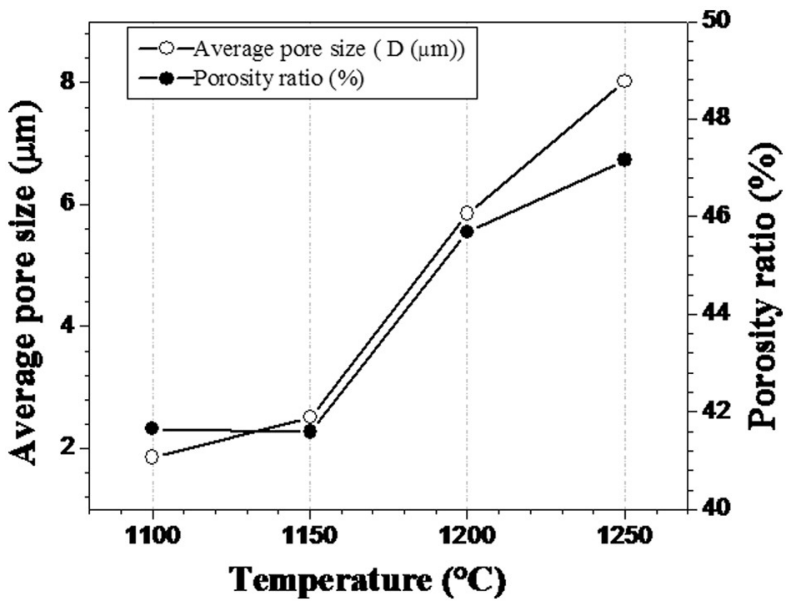

Fig. 10. Variation of porous volume and average pore size with a sintering temperature for $1 \mathrm{~h}$.
By contrast, for specimens sintered at 1200 and $1250{ }^{\circ} \mathrm{C}$, the majority of pores had a diameter lesser than $20 \mu \mathrm{m}$, ranging from 2 to $20 \mu \mathrm{m}$. As it may be seen in Fig. 11, when the sintering temperature rose from 1100 to $1250^{\circ} \mathrm{C}$, the curve of the pore size distribution moved towards larger pore sizes, and the \% volume of pores $<2 \mu \mathrm{m}$ decreased. In addition, the APS of specimens sintered at 1200 and $1250{ }^{\circ} \mathrm{C}$ is three times higher than that of specimens sintered at 1100 and $1150{ }^{\circ} \mathrm{C}$, respectively. It is worth to be mentioned that the increase in sintering temperature encourages the coalescence of pores which, in turn, leads to a larger APS. Furthermore, the pore size distribution of the membrane supports is a single (mono) distribution modal as illustrated in Fig. 11. This is a clear indication that the samples have a uniform pore size distribution.

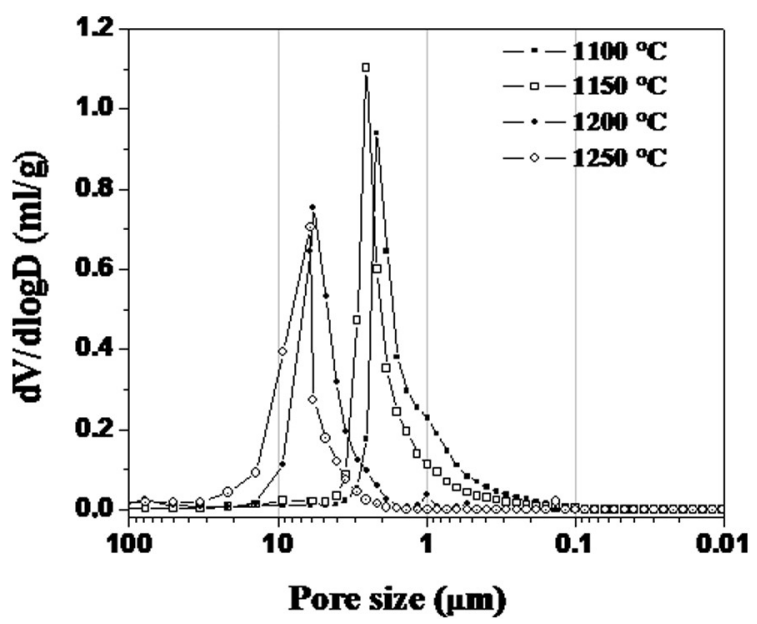

Fig. 11. Pore size distribution in samples sintered at different temperatures for $1 \mathrm{~h}$. 


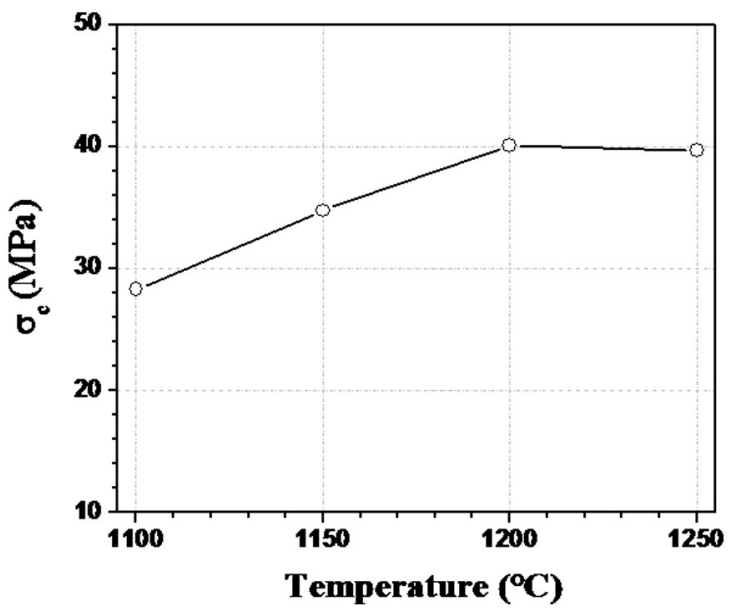

Fig. 12. Compressive strength as a function of sintering temperature for membrane supports.

\subsection{Compressive strength}

The mechanical resistance test was performed using the compressive strength. The effect of sintering temperature on the mechanical properties of the membrane supports was also investigated. Fig. 12 shows the changes in the compressive mechanical strength of the porous ceramics supports sintered at different temperatures (from 1100 to $1250^{\circ} \mathrm{C}$ ). The compressive strengths of specimens progressively increase with the increase in sintering temperature up to $1200^{\circ} \mathrm{C}$. After $1200{ }^{\circ} \mathrm{C}$, the compressive strength remains constant (around $40 \mathrm{MPa}$ ) with the increase in sintering temperature from 1200 to $1250{ }^{\circ} \mathrm{C}$. These mechanical properties are acceptable especially when MF and/or UF membrane applications are needed. Usually, densification and grain size are the dominant factors controlling the mechanical strength, since most of the total pores were intergranular. The substantial increase in strengths of samples corresponded to a parallel increase in density, which means a decrease in porosity ratio. This is true when a sinterable product such as anorthite is applied. Nevertheless, the presence of many phases, may delay this decrease afterwards. Hence, it can be assumed that the difference in strength only results from the change of sintering temperatures. The XRD patterns of samples sintered at different temperatures are shown in Fig. 8. The identified crystal phases are anorthite and gehlenite, which may be considered as the main factor controlling the strength of samples. The gehlenite $\left(2 \mathrm{CaO} \cdot \mathrm{Al}_{2} \mathrm{O}_{3} \cdot \mathrm{SiO}_{2}\right)$ is the main phase identified at $1100^{\circ} \mathrm{C}$. With the increase in sintering temperatures (up to $1200^{\circ} \mathrm{C}$ ), the crystalline gehlenite decreased gradually

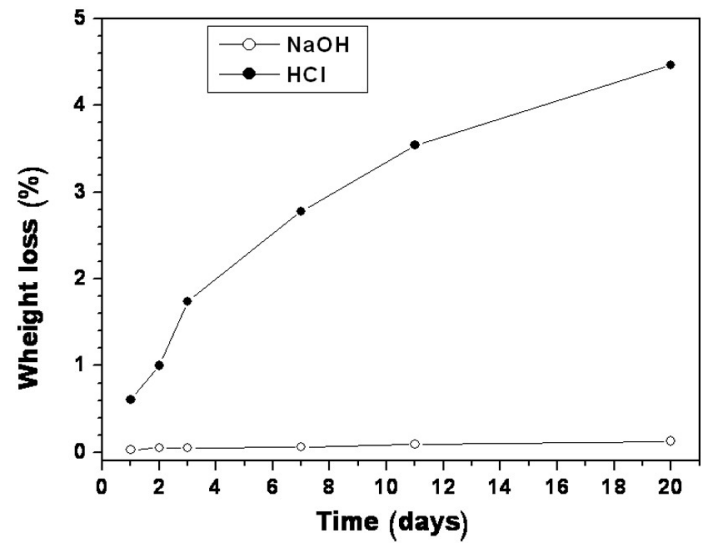

Fig. 13. Weight loss of support sintered at $1250{ }^{\circ} \mathrm{C}$ in the acidic $(\mathrm{HCl})$ and alkaline $(\mathrm{NaOH})$ solutions as a function of time.

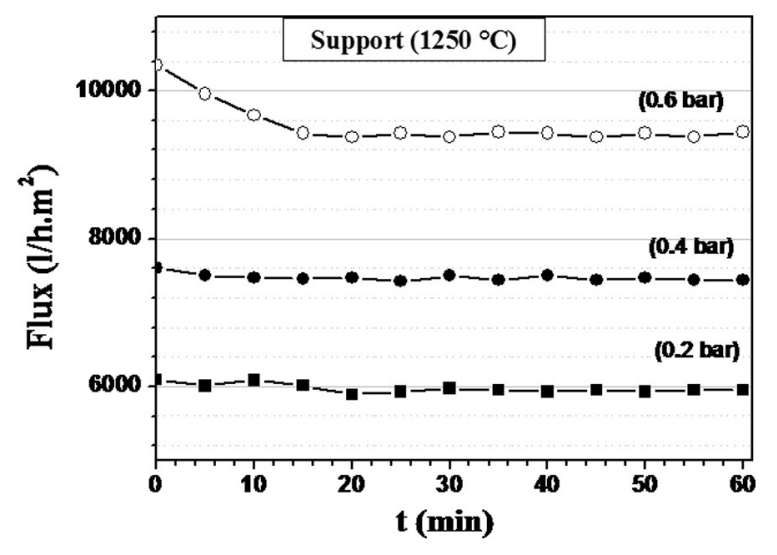

Fig. 14. Distilled water flux variation as a function of different pressures.

as shown from the reduction of peaks a, b and c in Fig. 8. After $1200{ }^{\circ} \mathrm{C}$, the crystalline gehlenite slightly decreases up to the sintering temperature of $1250^{\circ} \mathrm{C}$. These results indicate that the mechanical properties of obtained porous ceramics are strongly affected by the presence of certain phases such as anorthite and gehlenite. Compared to the porosity and APS, the nature of phases plays a more significant influence on strength.

\subsection{Chemical corrosion}

The chemical corrosion resistance, of the fabricated support sintered at $1250^{\circ} \mathrm{C}$, was evaluated by the mass loss after being immersed into $\mathrm{HCl}(\mathrm{pH}=2.5)$ and $\mathrm{NaOH}$ solutions $(\mathrm{pH}=12.5)$ at a room temperature for 20 days. The weight loss due to the corrosion of acids and alkali is shown in Fig. 13. It can be seen that the support shows a better alkali corrosion resistance, since its mass loss is much lower than those of supports after acid corrosion. This can be explained by the high alkali content of the considered ceramics [69].

Therefore, the observed results in weight loss during corrosion tests suggest that the prepared support possesses a good chemical corrosion resistance and it is suitable for applications involving acidic and basic media.

\subsection{Support water permeability}

The water permeability of the membrane support was measured. Fig. 14 shows the variation of water flux with time and pressures for

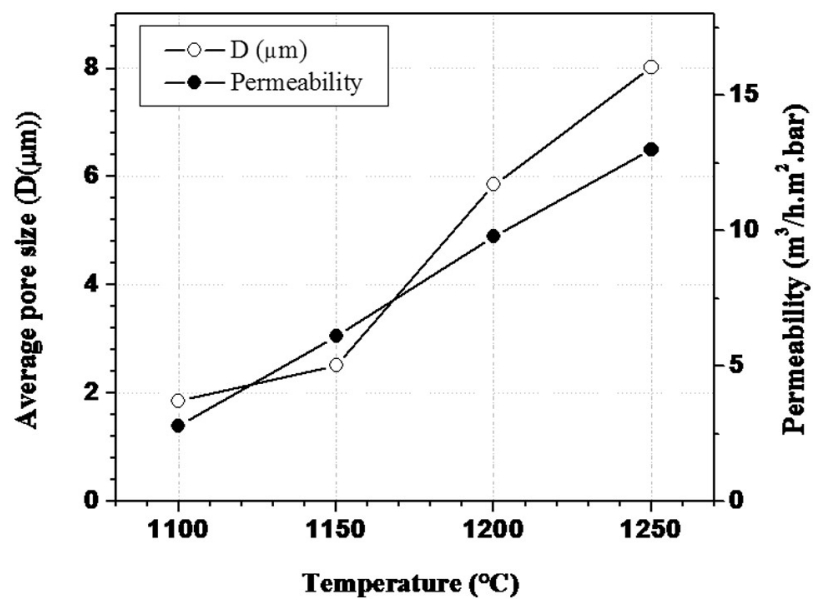

Fig. 15. Permeability and APS for membrane support sintered at different temperatures for $1 \mathrm{~h}$. 

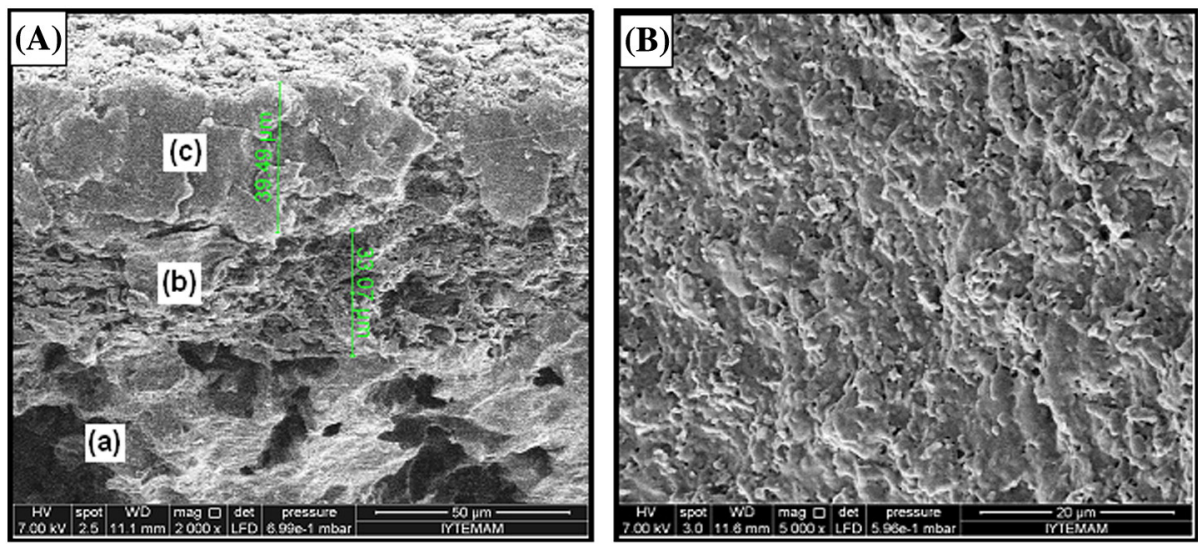

Fig. 16. SEM micrographs of multilayer system. A: cross-section; support (a), intermediate layer (b) and a top layer (c), B: surface of top layer membrane.

supports sintered at $1250^{\circ} \mathrm{C}$. A stable flux is obtained after few minutes. However, it depends on the applied pressure. The average water permeability is around $13 \mathrm{~m}^{3} / \mathrm{h} \cdot \mathrm{m}^{2} \cdot$ bar.

The distilled water permeability measurement for the prepared supports sintered at different temperatures is shown in Fig. 15. This figure shows that there is an increase in permeability values, when the sintering temperature is increased. As shown in Fig. 15, the water permeability of the support sintered at $1250{ }^{\circ} \mathrm{C}$ for $1 \mathrm{~h}$ is much higher than that of the supports sintered at 1100 and $1150{ }^{\circ} \mathrm{C}$. For example, a permeability of about $3 \mathrm{~m}^{3} / \mathrm{h} \cdot \mathrm{m}^{2}$. bar was achieved for supports sintered at $1100{ }^{\circ} \mathrm{C}$, with a porosity ratio of $\approx 42 \%$ and an APS around $1.9 \mu \mathrm{m}$, whereas a permeability of about $13 \mathrm{~m}^{3} / \mathrm{h} \cdot \mathrm{m}^{2} \cdot$ bar was obtained. By contrast, for supports sintered at $1250{ }^{\circ} \mathrm{C}$ the porosity ratio and APS values were $\approx 47 \%$ and $8 \mu \mathrm{m}$, respectively. The water flux through a porous structure is influenced by several variables according to the Hagen-Poiseuille equation [64]: the pore size, the porosity, the pressure difference across the support, the support thickness, the total porosity and the viscosity of water. The supports had identical thicknesses $(\approx 2 \mathrm{~mm})$ and were tested under the same conditions. On the basis of the above results, it can be said that the higher water permeability for supports sintered at $1250{ }^{\circ} \mathrm{C}$ is the result of two main factors: high porosity ratio and large APS. This high permeability is very important property for these membrane supports. Finally, the best conditions to prepare the support are established at a firing temperature of about $1250{ }^{\circ} \mathrm{C}$. Under these conditions, the APS, the porosity ratio, the permeability and the compression strength were about $8 \mu \mathrm{m}, 47 \%$, $13,000 \mathrm{l} / \mathrm{h} \cdot \mathrm{m}^{2} \cdot$ bar and $40 \mathrm{MPa}$, respectively.

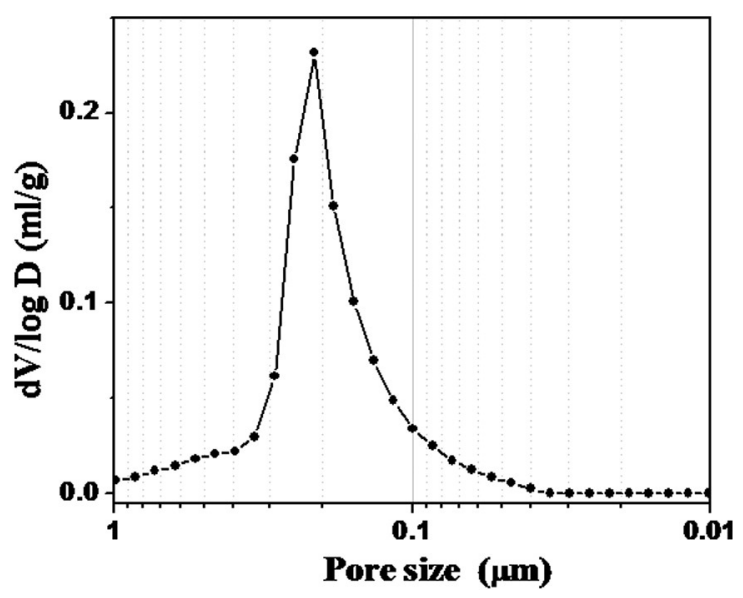

Fig. 17. Pore size distribution of top layer membrane sintered at $1050{ }^{\circ} \mathrm{C}$ for $1 \mathrm{~h}$.

\subsection{Membrane top layer characterization}

Fig. 16A shows a typical SEM micrograph of the cross-section: a multilayer system constituted of a macroporous support, an intermediate layer of TK and a top layer of TKH. It can be observed that a top layer deposited from a TKH on an intermediate layer has a uniform thickness and presents a good adhesion with the intermediate layer and its surface is homogeneous and without any defects and microcracks (Fig. 16B). The thickness of the layers may be controlled by the percentage of the mineral powder added into the suspension and the coating time. Under the used coating conditions, TK interlayer and TKH top layer have been produced within average thicknesses of about 33 and $40 \mu \mathrm{m}$, respectively. The pore size distribution of top layer was narrow, ranging from 0.06 to $0.3 \mu \mathrm{m}$, and is a single (mono) distribution modal [14] which confirms that the membrane has a uniform pore size distribution and an APS equal to $0.2 \mu \mathrm{m}$ (Fig. 17). This APS indicates that this kind of membranes can be utilized in the MF range. This APS value is considerably lower than those obtained for other typical ceramic MF membranes (about $0.5 \mu \mathrm{m}$ ) reported in previous works [9,11]. Even though, the researchers used relatively expensive oxides, such as $\mathrm{ZrO}_{2}$, for the preparation of their ceramic MF membranes.

The typical measured water flows through the multilayer system are given as a function of time and of a mean applied pressure, as illustrated in Fig. 18. The water flux increased at a higher applied pressure as expected and a stable flux is obtained after few minutes. The average water permeability is around $550 \mathrm{l} / \mathrm{h} \cdot \mathrm{m}^{2}$. bar while the dextran rejection is of about $10 \%$. The water sample characteristics, which were

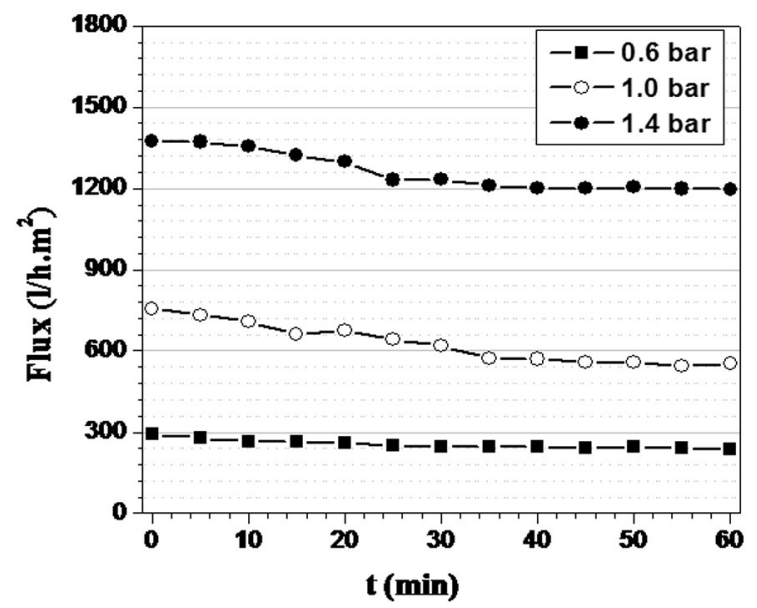

Fig. 18. Water flux versus times, at 3 working pressures, using distilled water. 
Table 4

Water sample characteristics before and after filtration.

\begin{tabular}{llclll}
\hline & Element & $\begin{array}{l}\text { Turbidity } \\
(\mathrm{NTU})\end{array}$ & $\begin{array}{l}\text { Conductivity } \\
(\mu \mathrm{s} / \mathrm{cm})\end{array}$ & $\begin{array}{l}\text { Salinity } \\
(\mathrm{mg} / \mathrm{l})\end{array}$ & $\mathrm{pH}$ \\
\hline \multirow{2}{*}{ Sample 1} & Before & 2.88 & 414 & 0.2 & 7.95 \\
& After & 0.80 & 370 & 0.2 & 8.10 \\
Sample 2 & Before & 121 & 335 & 0.2 & - \\
& After & 0.46 & 300 & 0.2 & - \\
\hline
\end{tabular}

obtained before and after filtration using the novel membranes, are presented in Table 4 . The permeability was characterized by measuring $\mathrm{pH}$, turbidity and conductivity. The obtained results show that $\mathrm{pH}$ value remains constant during all filtration tests. The effect of membrane on conductivity is negligible because MF process is not efficient to remove the soluble salts from effluents. Furthermore, the sintered MF membrane prepared from TKH presents a good chemical resistance towards the basic and acid solutions. The weight loss due to the corrosion of acids and alkali is shown in Fig. 19. In fact, this weight loss is negligible. It did not exceed $1 \%$ when a sample, which was immersed during 20 days into $\mathrm{HCl}(\mathrm{pH}=2.5)$ and $\mathrm{NaOH}$ solutions $(\mathrm{pH}=12.5)$ at a room temperature. The obtained results revealed that the prepared membrane shows greater corrosion resistance in both acidic and basic mediums as than that of the support. This latter is thought to be due to the nature of the existing phases. Hence, it can be used for membrane applications.

\section{Conclusions}

In this work, ceramic multilayer membranes in a tubular configuration were prepared. It consisted of an alternative support, one intermediate layer and a top layer. Ceramic supports have been obtained by extrusion using kaolin and calcium carbonates as starting materials. The prepared supports sintered at $1250{ }^{\circ} \mathrm{C}$ offer a better mechanical strength (40 MPa compression strength), chemical stability $(<5 \%$ weight loss in acidic media and negligible weight loss in basic media) good porosity (47\%), better average pore size $(8 \mu \mathrm{m})$ and high permeability. It has also been concluded that the membrane supports sintered at $1250{ }^{\circ} \mathrm{C}$ is the optimum supports allowed for depositing the membrane layers. In fact, due to the particular Texenna kaolin halloysite shape and sizes of particles, coupled with the larger pore diameter of the clay support, it was necessary to coat an intermediate layer with smaller pore sizes compared to the support. The intermediate layer has also the role of preventing the infiltration of suspensions into the support, allows a reduction of the thickness of the top layer and it even allows to eliminate the defects of the support (reduce the surface roughness). Moreover, microfiltration ceramic membranes were

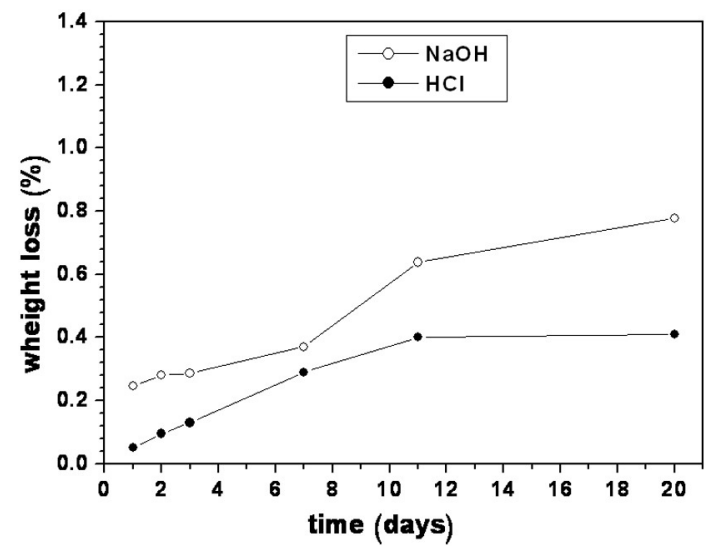

Fig. 19. Weight loss of MF top layer membrane in the acidic $(\mathrm{HCl})$ and alkaline $(\mathrm{NaOH})$ solutions as a function of time. prepared by slip casting method. It has been found that the microfiltration layer has an APS of about $0.2 \mu \mathrm{m}$, a narrow pore size distribution and a water permeability of $550 \mathrm{l} / \mathrm{h} \cdot \mathrm{m}^{2} \cdot$ bar.

This result may allow the novel membrane to be used in water treatment in the microfiltration range. A correlation between microstructures of used powders and physicochemical properties was discussed. Finally, the origin of the unique two powder order membrane depositions was also proposed.

\section{Acknowledgments}

The authors gratefully acknowledge the partial financial support received from the DGRSDT, Algeria, (Grant No 4/u250/822), and thank Prof. H. Ourag DGRSDT Director-General for equipment delivering facilities (Hg-Porosimeter, BET, FTIR, ...) and his continuous encouraging on the subject.

\section{References}

[1] A. Harabi, S. Achour, A process for sintering of $\mathrm{MgO}$ and $\mathrm{CaO}$ based ceramics, J. Mater. Sci. Lett. 18 (1999) 955-957.

[2] M.R. Boudchicha, S. Achour, A. Harabi, Crystallization and sintering of cordierite and anorthite based binary ceramics, J. Mater. Sci. Lett. 20 (2001) 215-217.

[3] A. Mecif, J. Soro, J.P. Bonnet, A. Harabi, Preparation of mullite and zircon based ceramics using kaolinite and zirconium oxide: a sintering study, J. Am. Ceram. Soc. 93 (2010) 1306-1312.

[4] A. Harabi, N. Karboua, S. Achour, Effect of thickness and orientation of alumina fibrous thermal insulation on microwave heating in a modified domestic $2.45 \mathrm{GHz}$ multi-mode cavity, Int. J. Appl. Ceram. Technol. 9 (1) (2012) 124-132.

[5] A. Harabi, T.J. Davies, Densification and grain growth in sintered alumina-chromia powder mixtures, Br. Ceram. Trans. J. 94 (2) (1995) 79-84.

[6] A. Harabi, T.J. Davies, Mechanical properties of sintered alumina-chromia refractories, Br. Ceram. Trans. J. 94 (3) (1995) 97-102.

[7] S. Kitouni, A. Harabi, Sintering and mechanical properties of porcelains prepared from Algerian raw materials, Cerâmica 57 (2011) 453-460.

[8] F. Bouzerara, A. Harabi, S. Achour, A. Labrot, Porous ceramic supports for membranes prepared from kaolin and doloma mixtures, J. Eur. Ceram. Soc. 26 (2006) 1663-1671.

[9] A. Harabi, F. Bouzerara, S. Condom, Preparation and characterization of tubular membrane supports using centrifugal casting, Desalin. Water. Treat. 6 (2009) 222-226.

[10] B. Boudaira, A. Harabi, F. Bouzerara, S. Condom, Preparation and characterization of microfiltration membranes and their supports using kaolin (DD2) and $\mathrm{CaCO}_{3}$. Desalin. Water. Treat. 9 (2009) 142-148.

[11] F. Bouzerara, A. Harabi, S. Condom, Porous ceramic membranes prepared from kaolin, Desalin. Water. Treat. 12 (2009) 415-419.

[12] A. Harabi, A. Guechi, S. Condom, Production of supports and membranes filtration from kaolin and limestone, Procedia Eng. 33 (2012) 220-224.

[13] F. Bouzerara, A. Harabi, B. Ghouil, N. Medjemem, B. Boudaira, S. Condom, Elaboration and properties of zirconia microfiltration membranes, Procedia Eng. 33 (2012) 78-84.

[14] A. Harabi, F. Zenikheri, B. Boudaira, F. Bouzerara, A. Guechi, L. Foughali, A new and economic approach to fabricate resistant porous membrane supports using kaolin and $\mathrm{CaCO}_{3}$, J. Eur. Ceram. Soc. 34 (2014) 1329-1340.

[15] L. Foughali, A. Harabi, S.E. Barama, F. Bouzerara, A. Guechi, B. Boudaira, Effect of sodium phosphate additions on mechanical properties of porous Sigue quartz sand, Desalin. Water. Treat. (2015)http://dx.doi.org/10.1080/19443994.2015. 1021100 (accepted for publication).

[16] A. Harabi, E. Harabi, S. Chehalatt, S. Zouai, N.E. Karboua, L. Foughali, Effect of $\mathrm{B}_{2} \mathrm{O}_{3}$ on mechanical properties of porous natural hydroxyapatite derived from cortical bovine bones sintered at $1050{ }^{\circ} \mathrm{C}$, Desalin Water Treat. 1021997 (2015)http://dx. doi.org/10.1080/19443994.2015.1021997 (accepted for publication).

[17] E. Harabi, A. Harabi, F.-Z. Mezahi, S. Zouai, N.E. Karboua, Sihem Chehalatt, Effect of $\mathrm{P}_{2} \mathrm{O}_{5}$ on mechanical properties of porous natural hydroxyapatite derived from cortical bovine bones sintered at $1050{ }^{\circ} \mathrm{C}$, Desalin. Water. Treat. (2015)http://dx.doi. org/10.1080/19443994.2015.1022000 (accepted for publication).

[18] E. Harabi, A. Harabi, L. Foughali, S. Chehlatt, S. Zouai, F.Z. Mezahi, Grain growth in sintered natural hydroxyapatite, Acta Phys. Pol. A (2015)http://dx.doi.org/10. 1080/19443994.2015.1022000 (accepted for publication).

[19] L. Foughali, A. Harabi, J.P. Bonnet, D. Smith, B. Boudaira, Effect of calcium phosphate addition on sintering of El-Oued quartz sand raw materials, Cerâmica 60 (2014) 546-551.

[20] F.Z. Mezahi, H. Oudadesse, A. Harabi, A. Lucas-Girot, Y. Le Gal, H. Chaair, G. Cathelineau, Dissolution kinetic and structural behaviour of natural hydroxyapatite vs. thermal treatment, J. Therm. Anal. Calorim. 95 (2009) 21-29.

[21] F.Z. Mezahi, H. Oudadesse, A. Harabi, A. Lucas-Girot, Effect of $\mathrm{ZrO}_{2}, \mathrm{TiO}_{2}$ and $\mathrm{Al}_{2} \mathrm{O}_{3}$ additions on process and kinetics of bonelike apatite formation on sintered natural hydroxyapatite surfaces, Int. J. Appl. Ceram. Technol. 9 (2012) 529-540.

[22] A. Harabi, S. Chehlatt, Preparation process of a highly resistant wollastonite bioceramics using local raw materials. Effect of $\mathrm{B}_{2} \mathrm{O}_{3}$ additions on sintering and mechanical properties, J. Therm. Anal. Calorim. 111 (2013) 203-211. 
[23] A. Harabi, D. Belamri, N. Karboua, F.Z. Mezahi, Sintering of bioceramics using modified domestic microwave oven: natural hydroxyapatite sintering, J. Therm Anal. Calorim. 104 (2011) 283-289.

[24] A. Harabi, S. Zouai, A new and economic approach to synthesize and fabricate bioactive diopside ceramics using a modified domestic microwave oven. Part 1: study of sintering and bioactivity, Int. J. Appl. Ceram. Technol. 11 (2014) 31-46.

[25] S. Chehlatt, A. Harabi, E. Harabi, S. Zouai, H. Oudadesse, S.E. Barama, Biological properties study of bioactive wollastonite containing $5 \mathrm{wt} . \% \mathrm{~B}_{2} \mathrm{O}_{3}$ prepared from loca raw materials, Desalin. Water. Treat. (2015)http://dx.doi.org/10.1080/19443994. 2015.1021105 (accepted for publication)

[26] S. Chehlatt, A. Harabi, H. Oudadesse, E. Harabi, In vitro bioactivity study of pure wollastonite prepared from local raw materials, Acta Phys. Pol. A (2015) (accepted for publication).

[27] A. Harabi, E. Harabi, A modified milling system, using a bimodal distribution of highly resistant ceramics. Part 1. A natural hydroxyapatite study, Mater. Sci. Eng. C (2015)http://dx.doi.org/10.1016/j.msec.2015.03.003 (accepted for publication).

[28] Y. Dong, B. Lin, J. Zhou, X. Zhang, Y. Ling, X. Liu, G. Meng, S. Hampshire, Corrosion resistance characterization of porous alumina membrane supports, Mater. Charact. 62 (2011) 409-418.

[29] J. Han, E. Oh, I. Song, The use of a diatomite-kaolin composite coating to design the pore characteristics of a sintered diatomite membrane, Ceram. Int. 40 (2014) 2221-2227.

[30] C.N. Djanganga, E. Kamseu, M. Kor Ndikontar, G.L. Nana, J. Soro, U.C. Melo, A. Elimbi, P. Blanchart, D. Njopwouo, Sintering behaviour of porous ceramic kaolin-corundum composites: phase evolution and densification, Mater. Sci. Eng. A 528 (2011) 8311-8318.

[31] J. Ha, E. Oh, I. Song, The fabrication and characterization of sintered diatomite for potential microfiltration applications, Ceram. Int. 39 (2013) 7641-7648.

[32] S. Kroll, L. Treccani, K. Rezwan, G. Grathwohl, Development and characterisation of functionalised ceramic microtubes for bacteria filtration, J. Membr. Sci. 365 (2010) 447-455.

[33] G. Chen, H. Qi, W. Xing, N. Xu, Direct preparation of macroporous mullite supports for membranes by in situ reaction sintering, J. Membr. Sci. 318 (2008) 38-44.

[34] D. Vasanth, G. Pugazhenthi, R. Uppaluri, Fabrication and properties of low cost ceramic microfiltration membranes for separation of oil and bacteria from its solution, J. Membr. Sci. 379 (2011) 154-163.

[35] S. Sarkar, S. Bandyopadhyay, A. Larbo, S. Cerneaux, New clay-alumina porous capillary supports for filtration application, J. Membr. Sci. 392-393 (2012) 130-136

[36] Y. Hong Wang, Y. Zhang, X. Liu, G. Yao Meng, Microstructure control of ceramic membrane support from corundum-rutile powder mixture, Powder Technol. 168 (2006) 125-133

[37] Y. Dong, S. Hampshire, J. Zhou, B. Lin, Z. Ji, X. Zhang, G. Meng, Recycling of fly ash for preparing porous mullite membrane supports with titania addition, J. Hazard. Mater. 180 (2010) 173-180.

[38] K. Ezziane, A. Belouatek, E. Selmane, B. Hmida, Treatment of dye and cadmium solutions using asymmetric kaolin porous tubular support, Desalination 250 (2010) 418-422

[39] G.E. Romanos, Th.A. Steriotis, E.S. Kikkinides, N.K. Kanellopoulos, V. Kasseelouri, J.D.F. Ramsay, P. Langlois, S. Kallus, Innovative methods for preparation and testing of $\mathrm{Al}_{2} \mathrm{O}_{3}$ supported silicalite-l membranes, J. Eur. Ceram. Soc. 21 (2001) 119-126.

[40] P. Monash, G. Pugazhenthi, Effect of $\mathrm{TiO}_{2}$ addition on the fabrication of ceramic membrane supports: a study on the separation of oil droplets and bovine serum albumin (BSA) from its solution, Desalination 279 (2011) 104-114.

[41] J.H. Han, E. Oh, B. Bae, I.H. Song, The effect of kaolin addition on the characteristics of a sintered diatomite composite support layer for potential microfiltration applications, Ceram. Int. 39 (2013) 8955-8962.

[42] Y. Dong, X. Feng, D. Dong, S. Wang, Elaboration and chemical corrosion resistance of tubular macro-porous cordierite ceramic membrane supports, J. Membr. Sci. 304 (2007) 65-75

[43] Jang-Hoon Ha, Oh. Eunji, In-Hyuck Song, The fabrication and characterization of sintered diatomite for potential microfiltration applications, Ceram. Int. 39 (2013) 7641-7648.

[44] J.H. Han, E. Oh, R. Ahmad, I.H. Song, The effects of pore structures on the air permeation properties of sintered diatomite, Ceram. Int. 39 (2013) 3881-3884.

[45] S.H. Lee, K.C. Chung, M.C. Shin, J.I. Dong, H.S. Lee, K.H. Auh, Preparation of ceramic membrane and application to the cross flow microfiltration of soluble waste oil, Mater. Lett. 52 (2002) 266-271.

[46] C. Gaucher, P. Jaouen, J. Comiti, P. Legentilhomme, Determination of cake thickness and porosity during cross-flow ultrafiltration on a plane ceramic membrane surface using an electrochemical method, J. Membr. Sci. 210 (2002) 245-258.
[47] H.K. Oh, S. Takizawa, S. Ohgaki, H. Katayama, K. Oguma, M.J. Yu, Removal of organics and viruses using hybrid ceramic, MF system without draining PAC, Desalination 202 (2007) 191-198.

[48] X. Changrong, G. Xiaoxia, L. Fanqing, P. Dingkun, M. Guangyao, Preparation of asymmetric Ni:ceramic composite membrane by electroless plating, Colloids Surf. A Physicochem. Eng. Asp. 179 (2001) 229-235.

[49] J.M. Benito, A. Conesa, F. Rubio, M.A. Rodriguez, Preparation and characterization of tubular ceramic membranes for treatment of oil emulsions, J. Eur. Ceram. Soc. 25 (2005) 1895-1903.

[50] F. Bouzerara, S. Boulanacer, A. Harabi, B. Boudaira, S. Achour, S. Condom, Preparation and characterization of macroporous ceramic supports for membranes, Phys. Procedia 2 (2009) 1449-1453.

[51] L.F. Han, Z.L. Xu, Y. Cao, Y.M. Wei, H.T. Xu, Preparation, characterization and permeation property of $\mathrm{Al}_{2} \mathrm{O}_{3}, \mathrm{Al}_{2} \mathrm{O}_{3}-\mathrm{SiO}_{2}$ and $\mathrm{Al}_{2} \mathrm{O}_{3}$-kaolin hollow fiber membranes, J. Membr. Sci. 372 (2011) 154-164.

[52] A. Majouli, S. Alami Younssi, S. Tahiri, A. Albizane, H. Loukili, M. Belhaj, Characterization of flat membrane support elaborated from local Moroccan Perlite, Desalination 277 (2011) 61-66

[53] J. Bai, Fabrication and properties of porous mullite ceramics from calcined carbonaceous kaolin and $\alpha-\mathrm{Al}_{2} \mathrm{O}_{3}$, Ceram. Int. 36 (2010) 673-678.

[54] N. Saffaj, M. Persin, S. Younsi, A. Albizane, M. Cretin, A. Larbot, Elaboration and characterization of microfiltration and ultrafiltration membranes deposited on raw support prepared from natural Moroccan clay: application to filtration of solution containing dyes and salts, Appl. Clay Sci. 31 (2006) 110-119.

[55] B.K. Nandi, R. Uppaluri, M.K. Purkait, Preparation and characterization of low cost ceramic membranes for micro-filtration applications, Appl. Clay Sci. 42 (2008) $102-110$.

[56] S. Bose, C. Das, Role of binder and preparation pressure in tubular ceramic membrane processing: design and optimization study using Response Surface Methodology (RSM), Ind. Eng. Chem. Res. 53 (2014) 12319-12329.

[57] R.D. Sahnoun, J. Bouaziz, Sintering characteristics of kaolin in the presence of phosphoric acid binder, Ceram. Int. 38 (2012) 1-7.

[58] A. Boulmokh, Y. Berredjem, K. Guerfi, A. Gheid, Kaolin from Djebel Debbagh Mine, Guelma, Algeria, J. Appl. Sci. 2 (4) (2007) 435-440.

[59] F. Bouzerara, S. Boulanacer, A. Harabi, Shaping of microfiltration (MF) $\mathrm{ZrO}_{2}$ membranes using a centrifugal casting method, Ceram. Int 41 (2015) 5159-5163.

[60] A. Harabi, B. Boudaira, F. Bouzerara, L. Foughali, F. Zenikheri, A. Guechi, B. Ghouil, S. Condom, Porous ceramic supports for membranes prepared from kaolin (DD3) and calcite mixtures, Acta Phys. Pol. A (2015) (accepted for publication).

[61] B. Boudaira, A. Harabi, F. Bouzerara, F. Zenikheri, A. Guechi, Preparation and characterization of membrane supports for microfiltration and ultrafiltration using kaolin (DD2) and $\mathrm{CaCO}_{3}$, Desalin. Water. Treat. (2015)http://dx.doi.org/10.1080/ 19443994.2015.1021998 (accepted for publication).

[62] A. Guechi, A. Harabi, S. Condom, F. Zenikheri, B. Boudaira, F. Bouzerara, L. Foughali, Elaboration and characterization of tubular supports for membranes filtration, Desalin. Water. Treat. (2015)http://dx.doi.org/10.1080/19443994.2015.1021096 (accepted for publication).

[63] B. Ghouil, A. Harabi, F. Bouzerara, Elaboration and characterization of ceramic membrane supports from raw materials used in microfiltration, Desalin. Water. Treat. (2015)http://dx.doi.org/10.1080/19443994.2015.1021098 (accepted for publication).

[64] J. Zhou, X. Zhang, Y. Wang, A. Larbot, X. Hu, Elaboration and characterization of tubular macroporous ceramic support for membranes from kaolin and dolomite, J. Porous. Mater. 31 (2006) 110-119.

[65] S. Bose, C. Das, Preparation and characterization of low cost tubular ceramic support membranes using sawdust as a pore-former, Mater. Lett. 110 (2013) 152-155.

[66] S. Bose, C. Das, Sawdust: from wood waste to pore-former in the fabrication of ceramic membrane, Ceram. Int. 41 (2015) 4070-4079.

[67] M. Kazemimoghadam, T. Mohammadi, Preparation of nano pore hydroxysodalite zeolite membranes using of kaolin clay and chemical sources, Desalination 278 (2011) 438-444.

[68] Tao Yang, Zheng-Fei Ma, Qi-Yong Yang, Formation and performance of kaolin/ $\mathrm{MnO}_{2}$ bi-layer composite dynamic membrane for oily wastewater treatment: effect of solution conditions, Desalination 270 (2011) 50-56.

[69] S. Fakhfakh, S. Baklouti, S. Baklouti, J. Bouaziz, Elaboration and characterisation of low cost ceramic support membrane, Adv. Appl. Ceram. 109 (2010) 3138. 